\title{
A MODULAÇÃO DOS EFEITOS TEMPORAIS DA DECISÃO EM CONTROLE CONCENTRADO DE CONSTITUCIONALIDADE: GARANTIA À SEGURANÇA JURÍDICA
}

\author{
Eloise Mari Gretter
}

Resumo: Por meio do art. 27 da Lei n. ${ }^{\circ}$ 9.868/99, o Supremo Tribunal Federal tem se utilizado da técnica de modulação dos efeitos temporais no controle concentrado de constitucionalidade das leis e atos normativos, que lhe permitem manipular o efeito contido nas decisões. O presente estudo aborda a evolução histórica no Brasil, os mecanismos de controle e a modulação dos efeitos da decisão em controle concentrado de constitucionalidade à luz do princípio constitucional da segurança jurídica.

Palavras-chaves: Controle concentrado de constitucionalidade. Modulação dos efeitos temporais. Princípios constitucionais. Segurança jurídica.

\section{INTRODUÇÃO}

O controle concentrado de constitucionalidade é exercido pelo Supremo Tribunal Federal, por atribuição que lhe foi conferida pela Constituição da Republica Federativa do Brasil de 1988.

Em razão de reiteradas decisões proferidas pela Corte, no sentido de possibilidade de modulação dos efeitos temporais

1 Bacharel em direito; servidora pública estadual. E-mail: eloise.mari@uol.com.br 
em controle concentrado de constitucionalidade, o legislador inseriu no ordenamento jurídico brasileiro as Leis n. ${ }^{\circ}$ 9.868/99 e 9.882/99, que regulamentam o processo e julgamento da ação direta de inconstitucionalidade, estabelecendo requisitos legais a serem observados para sua correta aplicação.

Um dos requisitos que se apresenta é o quorum de votação de 2/3 dos membros e outro é a observância da segurança jurídica ou interesse público. Por se tratar de cláusula abstrata, a segurança jurídica poderia ser utilizada como argumento para todo tipo de procedimento, adotando-se a modulação dos efeitos de forma desregrada e não de forma excepcional, conforme a real intenção do legislador.

Assim, considerando que o controle de constitucionalidade das leis e atos normativos tem por objetivo a consolidação dos valores inseridos na Constituição da República Federativa do Brasil de 1988, o presente estudo se propõe a analisar o tema sob o enfoque da segurança jurídica, tendo em vista a influência dos modelos norte-americano e austríaco no sistema de controle de constitucionalidade brasileiro.

Diante desta pesquisa, será possível analisar se a modulação dos efeitos temporais em controle concentrado de constitucionalidade visa garantir a efetivamente a segurança jurídica ou gera, na realidade, a insegurança jurídica, pelo fato de estar permitindo a eficácia, em determinado período, de norma declarada de conteúdo inconstitucional.

\section{DESENVOLVIMENTO}

O Controle de Constitucionalidade é uma das conseqüências da adoção pelos Estados de Constituições Rígidas, estabelecidas pelo Poder Constituinte Originário, que destaca a superioridade da norma constitucional sobre os demais atos normativos, fruto do poder legislativo constituído, de competência limitada pela Constituição. 


\subsection{Natureza Jurídica da Norma Inconstitucional no Controle Concentrado e Difuso}

Uma norma jurídica é perfeita - planos da existência, validade e eficácia - "quando, concluído o seu ciclo de formação, encontra-se plenamente ajustada às regras legais superiores e está disponivel para a deflagração dos efeitos que lhe são típicos" (BARROSO, 2009, p. 81).

A norma inconstitucional pode ser analisada sob dois prismas: no controle difuso e no controle concentrado.

O sistema de controle difuso é realizado pelo Poder Judiciário, por qualquer juiz ou tribunal, que analisa a inconstitucionalidade no caso concreto, de forma incidental e prejudicial de mérito. Este sistema teve sua origem no caso americano Marbury v. Madison que, em 1803, decidiu no sentido de que “...havendo conflito entre a aplicação de uma lei em um caso concreto e a Constituição, deve prevalecer a Constituição, por ser hierarquicamente superior" (MARSHALL apud LENZA, 2009, p. 178).

Nesse sentido, qualquer lei ou ato normativo que se afigure incompativel com o texto constitucional deve ser declarado nulo, aplicando-se a norma constitucional que lhe é hierarquicamente superior.

O sistema de controle concentrado, que é efetivado por meio do ato normativo em tese, de forma abstrata, tem por objeto principal a declaração de inconstitucionalidade da lei ou ato normativo que igualmente se mostre incompatível com o sistema.

Por meio deste sistema pretende-se “...expurgar do sistema lei ou ato normativo viciado (material ou formalmente), buscando-se, por conseguinte, a invalidação da lei ou ato normativo" (LENZA, 2009, p. 190).

O objeto de controle poderá ter como objeto:

a) a lei: conceito no qual se compreendem todas as espécies normativas previstas no art. 59 da Constituição da República Federativa do Brasil de 1988: 
Art. 59. O processo legislativo compreende a elaboração de: I - emendas à Constituição; II leis complementares; III - leis ordinárias; IV - leis delegadas; V - medidas provisórias; VI - decretos legislativos; VII - resoluções.

b) os atos normativos: estabelecidos pela doutrina como os atos administrativos dos tribunais, as deliberações administrativas dos órgãos judiciários e atos estatais, de conteúdo derrogatório.

Neste ponto, vale ressaltar que apenas as leis e atos normativos federais e estaduais podem ser objeto de controle perante o Supremo Tribunal Federal.

c) as emendas constitucionais: são passíveis de controle, porque são decorrentes do poder reformador, que deveria observar os limites impostos pelo poder constituinte originário.

Assim, não obedecidos os limites impostos pelo Poder Constituinte Originário, plenamente viável o controle de constitucionalidade e a conseqüente declaração de inconstitucionalidade da emenda que inseriu modificação no texto constitucional.

d) as medidas provisórias: há possibilidade de controle de constitucionalidade por se tratar de ato estatal, com força de lei, em pena vigência. O Supremo Tribunal Federal entendeu serem passíveis de controle - em caráter excepcional - os requisitos constitucionais de relevância e urgência.

e) os regulamentos subordinados ou de execução e decretos: como regra não são suscetíveis ao controle de constitucionalidade, em razão da ausência de força normativa, o que se torna aplicável, excepcionalmente, nos casos de decreto autônomo.

f) os tratados internacionais: o posterior reconhecimento da inconstitucionalidade do decreto legislativo que ratificou um tratado internacional não o torna nulo. Entretanto, a inconstitucionalidade do decreto afasta o seu cumprimento, sujeitandose à aplicação de sanções decorrentes de seu descumprimento. 


\subsection{Pressupostos do Controle de Constitucionalidade}

Dentre os pressupostos que viabilizam o controle de constitucionalidade em nosso sistema estão a rigidez e a supremacia constitucional.

A Constituição da República Federativa do Brasil de 1988 é classificada pela doutrina como rígida e, em especial, para alguns juristas, a exemplo de Alexandre de Moraes (MORAES, 2010), como super-rígida.

As constituições rígidas são aquelas que, para a alterabilidade de seu texto, exigem um processo legislativo diferenciado, mais solene e dificultoso do que o exigido no processo de alteração das normas infraconstitucionais (LENZA, 2009, p. 41). Ao passo que a denominação super-rígida deriva da existência de um núcleo intangivel, permanente e imutável.

A Constituição de 1988 apresenta em seu art. 60 um quorum diferenciado tanto para a propositura como para votação e aprovação de emendas constitucionais:

Art. 60. A Constituição poderá ser emendada mediante proposta:

I - de um terço, no mínimo, dos membros da Câmara dos Deputados ou do Senado Federal;

II - do Presidente da República;

III - de mais da metade das Assembléias Legislativas das unidades da Federação, manifestando-se, cada uma delas, pela maioria relativa de seus membros.

$\S 1$ - A Constituição não poderá ser emendada na vigência de intervenção federal, de estado de defesa ou de estado de sítio.

$\S 2 \circ$ - A proposta será discutida e votada em cada Casa do Congresso Nacional, em dois turnos, considerando-se aprovada se obtiver, em ambos, três quintos dos votos dos respectivos membros.

$\S 3^{\circ}$ - A emenda à Constituição será promulgada pelas Mesas da Câmara dos Deputados e do Senado Federal, com o respectivo número de ordem. 
E, em seu art. $60, \S 4 .^{\circ}$, a Carta Política atribuiu a um conjunto de matérias o caráter de cláusulas pétreas:

Art. 60, § 4 - Não será objeto de deliberação a proposta de emenda tendente a abolir:

I - a forma federativa de Estado;

II - o voto direto, secreto, universal e periódico;

III - a separação dos Poderes;

IV - os direitos e garantias individuais.

Estes preceitos se apresentam como permanentes, tendo o Supremo Tribunal Federal admitido a possibilidade de modificação para a sua ampliação e maior proteção, desde que, atendido o princípio da razoabilidade, a reforma não tenha como finalidade abolir aqueles direitos.

Nesse sentido, o ilustre professor José Afonso da Silva (2009, p. 45) define que:

A rigidez constitucional decorre da maior dificuldade para sua modificação do que para a alteração das demais normas jurídicas da ordenação estatal. Da rigidez emana, como primordial conseqüência, o princípio da supremacia da constituição, que no dizer de Pinto Ferreira, 'é reputado como uma pedra angular, em que se assenta o edifício do moderno direito político'. Significa que a constituição se coloca no vértice do sistema jurídico do país, a que confere validade, e que todos os poderes estatais são legítimos na medida em que ela os reconheça e na proporção por ela distribuídos. É, enfim, a lei suprema do Estado, pois é nela que se encontram a própria estruturação deste e a organização de seus órgãos; é nela que se acham as normas fundamentais de Estado, e só nisso se notará sua superioridade em relação às demais normas jurídicas.

Como conseqüência da maior dificuldade de alterabilidade do texto constitucional, a rigidez da Constituição Federal de 1988 acarreta sua supremacia, tanto material quanto formal, 
em relação às demais normas do ordenamento jurídico, como lei fundamental e suprema do Estado brasileiro.

Nas palavras do ilustre professor Luis Roberto Barroso (2009, p.134):

O princípio da supremacia da Constituição é fundamento da própria existência do controle de constitucionalidade, uma de suas premissas lógicas. Não pode, portanto, ser afastado ou ponderado sem comprometer a ordem e unidade do sistema.

$\mathrm{Na}$ concepção material, afiguram-se constitucionais as normas cujo conteúdo trata das matérias essenciais à organização do Estado e dos direitos fundamentais.

De outro norte, são constitucionalmente formais aqueles assuntos abordados na constituição, independentemente de seu conteúdo, em razão do seu processo de elaboração e aprovação.

Para que uma norma tenha validade dentro de um sistema rígido, em que a constituição se coloca em uma posição de superioridade em relação às demais normas, a norma deve "ser produzida em concordância com os ditames da Constituição, que representa seu fundamento de validade. A Constituição situa-se no vértice do sistema jurídico do Estado, de modo que as normas de grau inferior somente valerão se forem com ela compatíveis." (ALEXANDRINO, 2010, p. 308).

Desse modo, extrai-se que as normas que integram o ordenamento jurídico só serão válidas se estiverem em conformidade com as normas constitucionais. Eventual incompatibilidade será analisada através de controle de constitucionalidade pelo órgão estatal, que deve ser independente do órgão encarregado da produção normativa, ao qual a Constituição

atribua competência para verificação da conformidade das normas ordinárias com seus princípios e regras. Essa é outra decorrência relevante do princípio da supremacia constitucional: a necessidade de separação de poderes. Destarte, para que se tenha um efetivo sistema de controle de cons- 
titucionalidade dos comportamentos, leis e atos, normativos ou concretos, faz-se insofismável a necessidade de que se determine quem é competente para analisar e decidir se houve ou não ofensa à Constituição, como também qual o processo que deve ser utilizado para se anular uma conduta ou ato inconstitucional. É a própria Constituição que estabelece os órgãos encarregados de exercer tais competências e procedimentos especiais, que variam de um regime constitucional para outro e que consubstanciam o que denominamos controle de constitucionalidade. (ALEXANDRINO, 2010, p. 308).

\subsection{Natureza do Órgão de Controle de Constitucionalidade}

A natureza dos órgãos incumbidos da realização do controle pode ser política, judicial/jurisdicional mista ou híbrida, dependendo do sistema adotado pelo Estado em sua constituição.

No sistema político, o controle é exercido por um órgão distinto dos três Poderes, que confere à Constituição o seu status de supremacia. É um sistema comum na Europa, realizado por meio de Cortes ou Tribunais (LENZA, 2009, p. 171).

Destarte, há que se destacar que no Brasil há a possibilidade de controle repressivo político, realizado por órgãos políticos através do Poder Legislativo, do Poder Executivo e do Tribunal de Contas da União, como forma de exceção à regra geral do controle judicial.

Em nosso ordenamento, o controle repressivo exercido pelo Poder Legislativo pode decorrer da aplicação do art. 49, inciso $\mathrm{V}$, da $\mathrm{CF} / 88$, que estabelece:

É da competência exclusiva do Congresso Nacional: (...) V - sustar os atos normativos do Poder Executivo que exorbitem do poder regulamentar ou dos limites de delegação legislativa; (...) 


\title{
E, ainda, do art. 62 da CF/88:
}

Em caso de relevância e urgência, o Presidente da República poderá adotar medidas provisórias, com força de lei, devendo submetê-las de imediato ao Congresso Nacional.

Estes são os casos em que o Poder Legislativo atua, retirando do ordenamento jurídico os atos do Chefe do Poder Executivo, quando este extrapola seus limites ou quando não atende aos requisitos necessários para veiculação da Medida Provisória.

O Poder Executivo também exerce o controle de constitucionalidade repressivo quando o Chefe do Poder Executivo nega a execução de ato normativo que entender inconstitucional. $\mathrm{O}$ Supremo Tribunal Federal, assim como o Superior Tribunal de Justiça vêm decidindo acerca da

\begin{abstract}
possibilidade de descumprimento da lei inconstitucional pelo Chefe do Poder Executivo. Isso porque entre os efeitos do controle concentrado está a vinculação dos demais órgãos do Poder Judiciário e do Executivo (...) Outro argumento a fortalecer a idéia de possibilidade de descumprimento da lei flagrantemente inconstitucional pelo Executivo decorre dos efeitos da súmula vinculante (Reforma do Judiciário), que, uma vez editada, vinculará a Administração Pública, sob pena de responsabilidade civil, administrativa e penal (LENZA, 2009, p. 174).
\end{abstract}

Destaque-se, também, que o Tribunal de Contas da União, que auxilia o Congresso Nacional no controle externo, pode apreciar no caso concreto a constitucionalidade de uma lei e, em sendo o caso, deixar de aplicar a lei que lhe transpareça inconstitucional.

Por seu turno, o jurisdicional misto é o sistema adotado no Brasil como regra geral, em que o controle é realizado por órgãos do próprio Poder Judiciário. 
Quando ocorrer controle concentrado em face da Constituição Federal, o órgão competente será o Supremo Tribunal Federal e, quando se tratar do modelo difuso, será competente qualquer Juiz ou Tribunal, observadas as regras de competência estabelecidas no Código de Processo Civil.

No sistema híbrido, algumas leis são submetidas ao controle político e outras ao controle jurisdicional, através de órgão composto por membros do Poder Judiciário e membros políticos.

\subsection{Momento de Exercício do Controle de Constitucionalidade}

No que se refere ao seu momento, o controle de constitucionalidade pode ser prévio/preventivo - realizado antes mesmo de a norma estar apta a entrar em vigor, no plano das discussões político-legislativas, enquanto ainda projeto de lei ou posterior/repressivo/sucessivo - após a norma ter entrado em vigor, já inserida no ordenamento jurídico.

O controle de constitucionalidade prévio tem por objetivo fiscalizar a validade da norma, enquanto ainda projeto de lei ou de emenda constitucional, e impedir que ela entre em vigor caso seja incompativel com o atual ordenamento jurídico ou contrária ao interesse público.

Nesse caso, o controle "não declara a nulidade da medida, mas propõe a eliminação de eventuais inconstitucionalidades" (BARROSO, 2009, p.45).

No ordenamento jurídico brasileiro, o controle preventivo pode ocorrer de três maneiras distintas:

a) por meio da Comissão de Constituição e Justiça da Câmara dos Deputados e do Senado Federal (Poder Legislativo), que emitem parecer sobre a constitucionalidade da matéria examinada, realizando nítida fiscalização de constitucionalidade sobre os projetos de lei, proposta de emenda à constituição e outras. 
b) através do veto do Presidente da República (Poder Executivo), quando se baseia na inconstitucionalidade da norma (veto jurídico), incidindo sobre o projeto de lei (art. 66, § 1. ${ }^{\circ}$ da Constituição Federal).

c) ou, ainda, de modo excepcional, através de mandado de segurança impetrado por parlamentar (Poder Judiciário) durante o processo de elaboração de uma lei ou emenda constitucional quando este procedimento de elaboração da norma violar o "devido processo legislativo".

O Supremo Tribunal Federal adota o entendimento de que há possibilidade de intervenção do Poder Judiciário quando existir na Constituição vedação ao trâmite de determinada espécie normativa.

O controle posterior ocorre sobre a norma e não mais sobre o projeto de lei ou emenda constitucional e tem como objetivo expurgar do ordenamento jurídico as normas ou atos com conteúdo normativo que se apresentem incompativeis, seja em decorrência de vício formal (processo legislativo) ou material (conteúdo).

\section{5 Órgão Judicial Que Exerce o Controle de Constitucionalidade}

O ordenamento jurídico brasileiro estabelece, quanto ao órgão competente, que o controle de constitucionalidade pode ser difuso ou concentrado.

A principal característica do controle difuso ou aberto está no fato de a "competência para fiscalizar a validade das leis é [ser] outorgada a todos os componentes do Poder Judiciário, vale dizer, qualquer órgão do Poder Judiciário, juiz ou tribunal, poderá declarar a inconstitucionalidade das leis" (ALEXANDRINO, 2010, p. 313), observadas as competências de cada órgão.

O efeito da decisão independe do órgão prolator da decisão, pois a pretensão na via incidental é afastar a aplicação 
da lei ao caso concreto, alcançando apenas às partes vinculadas ao processo, com efeito, em regra, retroativo, não possuindo efeito vinculante (ALEXANDRINO, 2010, p. 323).

De outro norte, por decisão de dois terços de seus membros, o Supremo Tribunal Federal poderá outorgar efeitos prospectivos ou fixar outro momento como o termo inicial de eficácia de sua decisão.

Este tipo de sistema se verifica no caso concreto posto em análise, razão porque a declaração de inconstitucionalidade ocorre de forma incidental, prejudicialmente ao exame do mérito.

O controle concentrado ou abstrato de constitucionalidade é tarefa atribuída a tribunal superior do Poder Judiciário ou a uma corte especial, no caso do Brasil, realiza-se pelo Supremo Tribunal Federal, quando se estiver diante de uma inconstitucionalidade em face da Constituição Federal, ou pelos Tribunais dos Estados e Distrito Federal, quando a inconstitucionalidade se der frente à Constituição Estadual ou Lei Orgânica do Distrito Federal.

Tem-se que o controle abstrato

é efetivado em tese, sem vinculação a uma situação concreta, com o objetivo de expelir do sistema a lei ou ato inconstitucionais. Diz-se que no controle abstrato a inconstitucionalidade é examinada 'em tese' (in abstracto) porque o controle é exercido em uma ação cuja finalidade é, unicamente, o exame da validade da lei em si; a aferição da constitucionalidade da lei não ocorre incidentalmente, em um processo comum. (ALEXANDRINO, 2010, p. 331).

O controle concentrado em face da Constituição Federal pode ser realizado por meio das ações direta de inconstitucionalidade genérica (ADI), direta de inconstitucionalidade por omissão (ADO); declaratória de constitucionalidade (ADC); e argüição de descumprimento de preceito fundamental (ADPF). 


\title{
2.6 Forma de Controle Judicial de Constitucionalidade
}

Em se tratando da via eleita para verificação, o controle de constitucionalidade pode ser realizado através da via principal ou incidental.

No controle de constitucionalidade pela via incidental, a inconstitucionalidade é argüida incidentalmente no curso de um processo judicial, como questão prejudicial e premissa lógica do pedido principal, produzindo efeitos apenas entre as partes.

Esta forma de controle de constitucionalidade, também denominada de defesa ou de exceção, tem por finalidade a resolução de

\begin{abstract}
uma controvérsia concreta, submetida à apreciação do Poder Judiciário, em que uma das partes requer o reconhecimento da inconstitucionalidade de uma lei, com o fim de afastar a sua aplicação ao caso concreto de seu interesse. A apreciação da constitucionalidade não é o objeto principal do pedido, mas um incidente do processo, um pedido acessório. Por isso, a eventual declaração da inconstitucionalidade é dita incidental, incidenter tantum (o provimento judicial principal será o reconhecimento do direito pleiteado pela parte, decorrente do afastamento da lei àquele caso levado ao juízo). (ALEXANDRINO, 2010, p. 314).
\end{abstract}

Nesse sistema, o jurisdicionado requer ao Poder Judiciário a prestação jurisdicional para a resolução de seu conflito no caso concreto, como objeto principal. O pedido de declaração de inconstitucionalidade é objeto secundário do pedido, incidental, embora prejudicial ao mérito. $\mathrm{O}$ magistrado se obriga a primeiro analisar a constitucionalidade da norma para, posteriormente, decidir o mérito do pedido principal.

Por meio da via principal, determinadas autoridades detém competência para ajuizar ação autônoma (ADI, ADC, ADI por omissão, ADPF), em que a análise da constitucionalidade é o objeto exclusivo da causa, sem levar em conta qualquer caso concreto, com a finalidade de declarar a inconstituciona- 
lidade da norma, retirando-a definitivamente do ordenamento jurídico.

Desse modo, tem-se que o controle de constitucionalidade "é exercido fora de um caso concreto, independente de uma disputa entre partes, tendo por objeto a discussão acerca da validade da lei em si. Não se cuida de mecanismo de tutela de direitos subjetivos, mas de preservação da harmonia do sistema jurídico, do qual deverá ser eliminada qualquer norma incompatível com a Constituição" ( BARROSO, 2009, p.48).

O pedido principal da ação em controle concentrado de constitucionalidade pela via principal tutela direito objetivo, não envolve partes tampouco lide, $\mathrm{e}$

é a própria questão de constitucionalidade do ato normativo. $\mathrm{O}$ autor requer, por meio de uma ação judicial especial, uma decisão sobre a constitucionalidade, em tese, de uma lei, com o fim de resguardar a harmonia do ordenamento jurídico. $\mathrm{O}$ provimento judicial a que se visa consiste na declaração da compatibilidade, ou não, de certa norma jurídica ou conduta com as regras e princípios plasmados na Constituição. Nessa hipótese, não há caso concreto; portanto, não há interesses subjetivos específicos a serem tutelados. (ALEXANDRINO, 2010, p. 314).

O controle realizado pela via principal é decorrente do modelo Europeu, sendo associado, no Brasil ao controle concentrado, em caráter abstrato, acerca de uma norma em tese - não aplicada ao caso concreto.

\subsection{Teorias da Anulabilidade e Nulidade da Norma Inconstitucional}

A modulação dos efeitos temporais do controle concentrado de constitucionalidade tem em seu fundamento nos princípios da segurança jurídica, da proteção e da boa-fé. 
Ressalte-se que "a questão da eficácia temporal de decisão de inconstitucionalidade de uma norma é um problema de teoria do direito" (LUNARDI, 2009, p. 02), vez que depende se a teoria adotada é de que a lei inconstitucional é nula ou anulável.

Deve-se observar que, independente da teoria adotada (nulidade, anulabilidade ou possibilidade de modulação dos efeitos conforme a decisão dos julgadores), qualquer modificação no ordenamento jurídico acarreta conseqüências, que deverão ser analisadas e ponderadas sob a ótica dos princípios constitucionais e do interesse social.

O sistema austríaco de anulabilidade da norma inconstitucional, defendido por Kelsen, caracteriza-se pela prolação de uma decisão constitutiva, que reconhece inconstitucionalidade e anula a norma, que, até então, era válida e aplicável.

Neste caso, o vício se encontra no plano da existência, razão porque a Corte Constitucional Austríaca tem a possibilidade de

dispor que a anulação da lei opere somente a partir de uma determinada data posterior ('Kundmachung') de seu pronunciamento, contanto que este diferimento de eficácia constitutiva do pronunciamento não seja superior a um ano. (LENZA, 2009, p. 151)

A justificativa apontada por Hans Kelsen encontra respaldo na segurança jurídica e "no fato de que os legisladores também são intérpretes da Constituição, não cabendo ao Judiciário anular os efeitos resultantes do exercício da tarefa legislativa”. (OLIVEIRA, 2008, p. 05).

A teoria da nulidade foi adotada no Brasil por influência do direito norte-americano, em que a inconstitucionalidade de lei ou ato normativo é declarada como tal, afetando o plano da validade da norma.

Por se tratar de um ato meramente declaratório, que "reconhece uma situação pretérita, qual seja, o 'vício congênito', de 
'nascimento' do ato normativo" (LENZA, 2009, p. 150), ele apenas afasta a incidência da norma inconstitucional.

Cappelletti apud Pedro Lenza (2009, p. 151) assevera que:

a lei inconstitucional, porque contrária a uma norma superior, é considerada absolutamente nula ('null and void') e, por isso, ineficaz, pelo que o juiz, que exerce o poder de controle, não anula, mas, meramente, declara (pré-existente) nulidade da lei inconstitucional.

Nesse sentido, a decisão que declara a nulidade da lei inconstitucional, deve apresentar efeitos retroativos, em razão de a nulidade ser de natureza absoluta e esta decorrer diretamente da supremacia constitucional.

Registre-se que:

A doutrina nacional majoritária adota, desde Ruy Barbosa, o modelo estadunidense, considerando a decisão sobre a inconstitucionalidade de natureza declaratória. Decide-se que a norma sofre do vício de nulidade, tendo a decisão eficácia retroativa (ex tunc). Ora, se a norma é nula e o tribunal declara aquilo que ocorreu no momento de sua criação (e, em casos de inconstitucionalidade superveniente, desde determinado momento do passado), todos os efeitos gerados por essa norma devem ser declarados extintos e efetivamente desconsiderados, pois ela não tinha a força jurídica necessária para gerá-los (LUNARDI, 2009, p. 02-03).

O Supremo Tribunal Federal, em suas decisões, já esposou esse entendimento:

Atos inconstitucionais são, por isso mesmo, nulos e destituídos em conseqüência de qualquer carga de eficácia jurídica. A declaração de inconstitucionalidade de uma lei alcança, inclusive, os atos pretéritos com base nela praticados. (STF, ADI 652/MA)

Entretanto, esta teoria vem sendo flexibilizada no direito brasileiro em razão dos princípios constitucionais da segurança 
jurídica, da proteção e da boa-fé ponderados frente à estabilidade das relações jurídicas. Isto porque, a ineficácia da norma inconstitucional não pode ser compreendida de forma absoluta, uma vez que os efeitos jurídicos já produzidos e pendentes precisam ser regulamentados.

Extrai-se o entendimento do Supremo Tribunal Federal acerca do princípio da nulidade:

O afastamento de sua incidência dependerá de severo juízo de ponderação que, tendo em vista análise fundada no princípio da proporcionalidade, faça prevalecer a idéia de segurança jurídica ou outro princípio constitucionalmente relevante manifestado sob a forma de interesse social preponderante. Assim, aqui, a não aplicação do princípio da nulidade não se há de basear em consideração de política judiciária, mas em fundamento constitucional próprio. (STF, AI 631.533).

\subsection{Modulação dos Efeitos Temporais da Decisão em Controle Concentrado de Constitucionalidade e o Princípio Constitucional da Segurança Jurídica}

Pela necessidade de se regulamentar as situações jurídicas já consolidadas pela norma declarada inconstitucional e acompanhando o entendimento que vem sendo manifestado pelo Supremo Tribunal Federal foi editada a Lei n. ${ }^{\circ}$ 9.868, de 10 de novembro de 1999, que previu, em seu art. 27, a possibilidade de modular os efeitos temporais no controle concentrado de constitucionalidade:

Ao declarar a inconstitucionalidade de lei ou ato normativo, e tendo em vista razões de segurança jurídica ou de excepcional interesse social, poderá o Supremo Tribunal Federal, por maioria de dois terços de seus membros, restringir os efeitos daquela declaração ou decidir que ela só tenha 
eficácia a partir de seu trânsito em julgado ou de outro momento que venha a ser fixado.

E, na sequência, foi editada a Lei n. 9.882 de 03 de dezembro de 1999, que igualmente assinalou, em seu art. 11:

Ao declarar a inconstitucionalidade de lei ou ato normativo, no processo de argüição de descumprimento de preceito fundamental, e tendo em vista razões de segurança jurídica ou de excepcional interesse social, poderá o Supremo Tribunal Federal, por maioria de dois terços de seus membros, restringir os efeitos daquela declaração ou decidir que ela só tenha eficácia a partir de seu trânsito em julgado ou de outro momento que venha a ser fixado.

Destarte, verifica-se que os modelos da anulabilidade e nulidade convergem em uma terceira teoria, admitindo a possibilidade de os julgadores aplicarem a modulação dos efeitos na decisão, conforme os critérios legais, aproximando, de certa forma, os modelos americano e austríaco com a finalidade de "evitar que a declaração de inconstitucionalidade cause danos maiores que os benefícios esperados pelo afastamento da norma incompatível com a Constituição" (LUNARDI, 2009, p. 04).

A aplicação da modulação dos efeitos temporais em decisões de controle concentrado de constitucionalidade tem como balizas a segurança e a efetividade do próprio controle e da concretização constitucional da jurisdição, eis que se trata:

de uma válvula de segurança da efetividade do controle, de constitucionalidade, pois visa evitar que o Tribunal Constitucional deixe de declarar a inconstitucionalidade de uma lei diante das indesejadas conseqüências sociais que poderiam advir dessa decisão. Para que isso não ocorra, é possibilitada a adequação do decisum a situações reais. Dito de maneira mais política, o modelo da modulação permite que os Tribunais Constitucionais decidam sobre a inconstitucionalidade sem se sentir "pres- 
sionados" pelos inconvenientes do efeito retroativo quando se trata de situações consolidadas. Em nossa opinião trata-se de uma norma de calibração, que abre mão do rigor teórico (nulidade ou anulabilidade) para não comprometer a unidade e estabilidade do sistema jurídico e social. Isso torna central a figura do julgador, chamado a "ponderar" interesses e prioridades para decidir sobre os efeitos de cada decisão (LUNARDI, 2009, p. 04).

Para a aplicação desta técnica há a necessidade de observância de dois requisitos legais: decisão proferida por dois terços dos membros do Supremo Tribunal Federal, bem como observar a segurança jurídica ou o interesse social.

Conforme observa o ilustre professor Canotilho,

o homem necessita de segurança para conduzir, planificar e conformar autônoma e responsavelmente a sua vida. Por isso, desde cedo se consideravam os princípios da segurança jurídica e da proteção à confiança como elementos constitutivos do Estado de Direito. (CANOTILHO, 1999, p. 252).

A intenção do legislador ao editar tal possibilidade caminha ao encontro dos princípios e garantias constitucionalmente previstas. Embora possa estabelecer um período de transição, em que a norma declarada inconstitucional permaneça vigente e eficaz, seu fundamento é a manutenção da segurança jurídica das relações já concretizadas sob sua égide ou pendente de efeitos, bem como resguardar o interesse social, preservandose os atos praticados com boa-fé.

Percebe-se que a modulação dos efeitos temporais

permite uma melhor adequação da declaração de inconstitucionalidade, assegurando, por conseqüência, outros valores também constitucionalizados, como os da segurança jurídica, do interesse social e da boa fé (LENZA, 2009, p. 155).

A possibilidade de modulação dos efeitos temporais da decisão proferida em controle concentrado de constitucionali- 
dade revela-se de grande importância, porque analisa a lei em tese, por meio de ponderação dos princípios constitucionais, do interesse social, da adequação e interpretação conforme a constituição.

Como regra, a decisão de mérito tem efeito erga omnes, ex tunc, vinculante e repristinatório. Entretanto, presentes as condições legais, há a possibilidade de o Supremo Tribunal Federal restringir os efeitos da decisão, concedendo

efeitos prospectivos à declaração de inconstitucionalidade, tanto a partir do trânsito em julgado (efeito ex nunc) ou a partir de outro momento. Esse momento pode ser tanto posterior ao trânsito em julgado (estipulação de prazo para o início de produção de efeitos - efeito pro futuro), como anterior à decisão (mas sempre posterior à entrada em vigor da norma inconstitucional). (LUNARDI, 2009, p. 05).

Ao conferir efeitos ex nunc ou pro futuro, está-se criando

um espaço de tempo, intermediário, que assegure a sobrevivência provisória da lei declarada incompatível com a Constituição (...) Isso de tal sorte que possa o autor das leis - o Poder Legislativo - eleger um desses caminhos: revogar a lei, modificá-la ou completá-la, se para tanto for movido ou despertado pelo aresto judicial da Corte competente. (BONAVIDES, 2009, p. 341)

No sistema jurídico brasileiro tem-se desenvolvido técnicas de interpretação constitucional que permitem a suspensão dos efeitos da lei em caráter excepcional, até que a decisão definitiva seja prolatada, além de possibilitar que o Supremo Tribunal Federal module os efeitos de suas decisões, por meio de técnicas de declarações parciais ou totais de constitucionalidade ou inconstitucionalidade, efeitos ex tunc, ex nunc, pro futuro e interpretação conforme a constituição.

Desse modo, verifica-se que o legislador possibilitou a adoção de medidas no sentido de declaração total ou parcial de 
nulidade da norma, aproveitando-se no que restar compatível com o ordenamento jurídico.

Existindo mais de uma interpretação possível para a referida norma, os julgadores devem optar por aquela que melhor traduza a vontade e intenção do legislador, observando-se os princípios constitucionais, através da declaração de inconstitucionalidade sem redução de texto.

Ressalte-se que o Supremo Tribunal Federal proferiu, em algumas oportunidades, decisões com modulações de seus efeitos com o intuito de dar interpretação conforme a constituição a certos dispositivos normativos, preservando-se as situações reais frente aos princípios constitucionais.

Nas palavras do ilustre professor Luís Roberto Barroso (2009, p.134):

O que o Supremo Tribunal Federal poderá fazer ao dosar os efeitos retroativos da decisão é uma ponderação entre a norma violada e as normas constitucionais que protegem os efeitos produzidos pela lei inconstitucional. Como por exemplo: boa-fé, moralidade, coisa julgada, irredutibilidade dos vencimentos, razoabilidade.

E prossegue, no que se refere ao art. 27 da Lei 9.868/99:

Dele se pode extrair um caráter limitador da competência do Supremo Tribunal Federal para restringir os efeitos retroativo da decisão de inconstitucionalidade. De fato, para que a Corte possa decidir a ponderação de valores em favor da proteção dos efeitos da norma declarada inconstitucional - negando, assim, eficácia ex tunc à decisão - , passou a ser necessário o quórum de dois terços de seus membros (...) O dispositivo, a bem da verdade, tem sido utilizado com cautela e parcimônia. Rememore-se que a idéia de modulação dos efeitos temporais das decisões judiciais, que a ele se encontra subjacente, tem sido invocada pelo próprio Supremo Tribunal Federal, em outros cenários, como no controle incidental 
e na mudança de jurisprudência consolidada. (BARROSO, 2009, p. 134)

A exigência de um quorum especial (dois terços) garante o caráter excepcional da modulação do efeito temporal no controle de constitucionalidade, de forma que, realmente, aplique-se nos casos em que se verifique a necessidade de se preservar e garantir a segurança jurídica ou o interesse social.

Destaca-se a função determinante atribuída ao Supremo Tribunal Federal de concretizar a interpretação das cláusulas abstratas 'segurança jurídica' e 'interesse social' e de realizar um juízo de ponderação entre os princípios constitucionais conflitantes. (LUNARDI, 2009, p. 05).

Nesse particular, a cláusula aberta "segurança jurídica", constante no texto legal como pressuposto para a aplicação da modulação dos efeitos temporais na decisão em controle concentrado de constitucionalidade,

dá margem para que se entenda ter o Supremo Tribunal Federal o poder de restringir os efeitos da declaração de inconstitucionalidade nos mais variados casos, porquanto dificilmente uma norma constitucional não estará abrangida por aquelas razões. Neste contexto é que se revela a importância do preceito da proporcionalidade, nas suas três dimensões (necessidade, adequação e proporcionalidade em sentido estrito), pois o peso de cada um dos princípios constitucionais contrapostos no caso concreto é que definirá qual a solução mais justa na fixação dos efeitos da decisão. (OLIVEIRA, 2008, p. 12)

Luis Roberto Barroso (2009, p.64) destaca acerca das normas e da segurança jurídica que:

Modernamente, generaliza-se o entendimento de que a norma não é apenas o enunciado abstrato, mas o produto de sua interação com a realidade. Norma é o produto da interação entre o enunciado normativo e a realidade fática. Nesse ambiente, o Direito é aquilo que o Tribunal competente diz que 
ele é. Para que as pessoas possam ter previsibililide nas suas condutas e estabilidade nas suas relações jurídicas, é preciso que esse Direito seja constante.

Segundo José Afonso da Silva, a segurança jurídica tem seu fundamento de validade na própria Constituição, em perfeita harmonia com o valor de justiça social "na medida em que a Constituição tem por missão assegurar a vigência e eficácia do princípio da dignidade da pessoa humana, em que se centram todas as demais manifestações dos direitos fundamentais do homem" (SILVA, 2009, p. 16).

O princípio constitucional da segurança jurídica vem estampado na Constituição da República Federativa do Brasil em seu preâmbulo e no caput dos artigos $5^{\circ}$ e $6^{\circ}$, razão porque a interpretação constitucional se revela de suma importância para concretizar o sentido da norma constitucional no contexto da realidade que se observa (HESSE, 1991, p. 22-23).

Até porque, como ressalta Recanses Siches "o direito não nasceu na vida humana por virtude do desejo de prestar culto ou homenagem à idéia de justiça, mas para satisfazer uma ineludível urgência de segurança e de certeza na vida social” (SICHES apud SILVA, 2004, p. 15).

A segurança jurídica se fundamenta na garantia de estabilidade e certeza das relações jurídicas num dado ordenamento jurídico, permitindo plena ciência aos indivíduos acerca os efeitos de suas condutas, resguardando-se de eventual futura alteração legislativa. Ela - a segurança jurídica - está diretamente relacionada à garantia geral de direitos resguardados constitucionalmente (SILVA, 2009, p. 17).

Assim, pode-se dizer que a segurança jurídica "consiste na proteção conferida pela sociedade a cada um de seus membros para conservação de sua pessoa, de seus direitos e de suas propriedades" (BARROSO, 2001, p.50-51).

Na visão de Gilmar Ferreira Mendes (2009, pág. 14):

Ainda que provoque alguma insegurança, o reconhecimento de uma situação de transitoriedade 
tolerável amplia as perspectivas do controle de constitucionalidade, outorgando ao tribunal uma alternativa à simples afirmação ou negação da validade da lei. Por outro lado, há de se reconhecer que, não raras vezes, amplas reformas exigidas pelo texto constitucional não podem ser implementadas de forma imediata, carecendo de um prazo razoável de maturação. Nesse caso, a declaração de nulidade das normas em vigor, além de impedir uma reforma gradual, pode levar a um vácuo legislativo. Assim, não fosse esse recurso, a questão da inconstitucionalidade deixaria de ser apreciada, sob a invocação do postulado da judicial self-restraint, ou de outra cláusula de exclusão.

Sendo assim, tem-se que a segurança jurídica é um instrumento próprio e eficaz para a garantia da estabilidade do ordenamento jurídico, pois, resguarda os efeitos já produzidos durante a sua vigência, com a possibilidade de regulamentação dos efeitos pendentes de atos praticados durante a vigência da norma inconstitucional.

Diante do exposto, tem-se que a segurança jurídica prevista nos artigos 27 da Lei n. ${ }^{\circ}$ 9.868/99 e 11 da Lei n. ${ }^{\circ}$ 9.882/99, deve ser analisada como garantia da estabilidade das relações jurídicas, pois "se a lei for contrária à Constituição, sua manutenção contrariará a estabilidade do ordenamento regido por tal Constituição, possibilitando a incerteza quanto à estabilidade das normas constitucionais de determinado Estado" (SORMANI, 2004, p. 43).

Desse modo, a modulação dos efeitos temporais em controle de constitucionalidade das leis tem por finalidade a garantia da segurança jurídica, que não é a própria justiça, mas um meio para alcançá-la, justificando o reconhecimento das relações jurídicas efetivadas durante a vigência da norma inconstitucional, inclusive com sua aplicação posterior, no caso de efeitos pendentes.

Assim, a decisão que prime pela justiça deve observar criteriosamente os princípios e garantias constitucionais, em especial 
a segurança jurídica, a proporcionalidade, a boa-fé dos indivíduos e a presunção de constitucionalidade das leis. Isso porque, estas razões vêm sendo constantemente argüidas nos debates acerca da modulação dos efeitos da declaração de inconstitucionalidade pelos ministros do Supremo Tribunal Federal.

\section{CONCLUSÃO}

O ordenamento jurídico deve constantemente se atualizar como forma de acompanhar a evolução das relações sociais. Nesse sentido, a evolução jurisprudencial firmada pelo Supremo Tribunal Federal, no que se refere ao controle concentrado de constitucionalidade, demonstra o comprometimento dos eminentes Ministros, os mais graduados aplicadores do direito, em buscar a melhor solução para a manutenção da supremacia constitucional, observando-se os princípios constitucionais, em especial a segurança jurídica e a proporcionalidade.

A supremacia constitucional garante a segurança jurídica, a previsibilidade e a estabilidade das relações sociais aos indivíduos, configurando a confiança necessária que se exige em um Estado Democrático de Direito.

O ordenamento jurídico brasileiro, por influência do direito norte-americano, adotou a teoria da nulidade da norma inconstitucional, que confere efeitos ex nunc à decisão que declara a inconstitucionalidade. Entretanto, tal teoria vem sendo flexibilizada em razão da previsão legal de possibilidade de modulação dos efeitos temporais em decisão proferida em controle concentrado de constitucionalidade.

As Leis n. ${ }^{\circ}$ 9.868/99 e 9.882/99 trouxeram a previsão de modulação dos efeitos temporais em decisão proferida em controle de constitucionalidade, observados dois requisitos: o quorum de deliberação e o fundamento de segurança jurídica ou interesse público.

Com a possibilidade de modulação dos efeitos da decisão a partir do trânsito em julgado (ex nunc), ou de outro momento, 
ex tunc (limitado à data em que entrou em vigência) ou pro futuro, busca-se evitar efeitos danosos às relações jurídicas consolidadas ou pendentes de produção de seus efeitos. Isto porque, atendendo ao princípio da segurança jurídica, que é o mínimo de previsibilidade necessária que um Estado Democrático de Direito deve garantir aos indivíduos, acerca das normas jurídicas válidas e eficazes.Com a possibilidade de modulação dos efeitos ex tunc ou pro futuro.

Destarte, tem-se que uma Constituição deve manter sua supremacia, com a declaração da inconstitucionalidade das normas que com ela conflitem. Entretanto, ela também deve ter mecanismos para preservar a confiança depositada no ordenamento jurídico, protegendo o direito daqueles que, de boa-fé, realizaram atos jurídicos durante sua vigência, razão porque é de extrema importância a utilização o princípio da segurança, com razoabilidade e ponderação, pelos ministros do Supremo Tribunal Federal, em busca da finalidade última que é a justiça.

Abstract: Through the art. 27 of Law No. 9.868/99, the Supreme Court has used the technique of modulation of temporal effects in the concentrated control of constitutionality of laws and normative acts, which allow you to manipulate the effect contained in the decisions. The study examines the historical development in Brazil, the control mechanisms and modulation of the effects of the decision in concentrated control of constitutionality in light of the constitutional principle of legal certainty.

Keywords: Concentrated control of constitutionality. Modulation of temporal effects. Constitutional principles. Legal certainty. 


\section{REFERÊNCIAS}

ALEXANDRINO, Marcelo; PAULO, Vicente. Resumo de direito constitucional descomplicado. 3. ed. Rio de Janeiro: Forense, 2010.

BARROSO, Luís Roberto. O controle de constitucionalidade no direito brasileiro. E-book, 4. ed. São Paulo: Saraiva, 2009.

. O direito constitucional e a efetividade de suas normas: limites e possibilidades da Constituição brasileira. 9. ed. Rio de Janeiro, 2009.

. Temas de Direito Constitucional. Rio de Janeiro: Renovar: 2001.

BONAVIDES, Paulo. Curso de direito constitucional. 24. ed. São Paulo: Malheiros, 2009.

BRASIL. Constituição (1988). Constituição da República Federativa do Brasil: promulgada em 5 de outubro de 1988. Contém as emendas constitucionais posteriores. Brasília, DF: Senado, 1988.

BRASIL. Lei n. 9.868 de 10 de novembro de 1999. Disponível em: http:// www.planalto.gov.br/ccivil_03/Leis/L9868.htm. Acesso em 20 ago. 2010.

BRASIL. Lei n. 9.882 de 03 de dezembro de 1999. Disponível em: http:// www.planalto.gov.br/ccivil_03/Leis/L9882.htm. Acesso em 20 ago. 2010.

CANOTILHO, J.J. Gomes. Direito Constitucional e Teoria da Constituição. 3.ed. (reimpressão). Coimbra: Almedina, 1999.

HESSE, Konrad. A Força Normativa da Constituição. Traduzido por Gilmar Ferreira Mendes. Porto Alegre: Sergio Antônio Fabris, 1991.

LENZA, Pedro. Direito constitucional esquematizado. 13. ed. São Paulo: Saraiva, 2009.

LUNARDI, Soraya Gasparetto. Modulação temporal dos efeitos no processo de controle de constitucionalidade e influência de argumentos econômicos. Revista Brasileira de Estudos Constitucionais - RBEC. Material da 8. aula ministrada no Curso de Pós-Graduação Lato Sensu TeleVirtual em Direito Constitucional - Anhanguera-Uniderp | REDE LFG, 2009.

MENDES, Gilmar Ferreira. Controle de Constitucionalidade. Cadernos de Direito Constitucional - EMAGIS. Disponível em: http://www.trf4.jus.br/ trf4/upload/arquivos/emagis_prog_cursos/ccp5_gilmar_ferreira_mendes. pdf. Acesso em 22 ago. 2010. 
. Controle de Constitucionalidade. Constitucionalidade e

Inconstitucionalidade. Capítulo I. Seção I. Material da $1^{\mathrm{a}}$ aula ministrada no Curso de Pós-Graduação Lato Sensu TeleVirtual em Direito Constitucional - Anhanguera-UNIDERP | REDE LFG, 2009.

. Controle de Constitucionalidade: uma análise das leis 9868/99e

9882/99. Revista Eletronica de Direito do Estado n. ${ }^{\circ}$ 19. Salvador/BA, jul-set. 2009. Disponível em http://www.direitodoestado.com/revista/ REDE-19-JULHO-2009-GILMAR \%20MENDES.pdf. Acesso em 14 out. 2010 .

- O Princípio da Proporcionalidade na Jurisprudência do Supremo Tribunal Federal: Novas Leituras. Revista Diálogo Jurídico. Disponível em: http://www.direitopublico.com.br/pdf_5/DIALOGO-JURIDICO-05AGOSTO-2001-GIL MAR-MENDES.pdf. Acesso em: 16 jan. 2011.

OLIVEIRA, Aline Lima de. A limitação dos efeitos temporais da declaração de inconstitucionalidade no Brasil: uma análise da influência dos modelos norteamericano, austríaco e alemão. Porto Alegre: EDIPUCRS, 2008. Disponível em: http://www.pucrs.br/ edipucrs/efeitostemporais/index.html. Acesso em 30 jan. 2011.

SILVA, José Afonso. Curso de direito constitucional positivo. 32. a ed. São Paulo: Malheiros, 2009.

. Constituição e Segurança Jurídica. In ANTUNES, Carmem Lúcia

(org.). Constituição e Segurança Jurídica: direito adquirido, ato jurídico perfeito e coisa julgada. Estudos em homenagem a José Paulo Sepúlveda Pertence. Belo Horizonte: Fórum, 2004.

SORMANI, Alexandre. Inovações da ação direta de inconstitucionalidade e da ação declaratória de constitucionalidade: uma visão crítica da Lei n. 9.868/99 sob o viés do princípio da segurança jurídica. São Paulo: Juarez Freitas, 2004.

STRECK, Lenio Luiz. Teoria da Constituição e Jurisdição Constitucional. Cadernos de Direito Constitucional - EMAGIS. Disponível em http:// www.trf4.jus.br/trf4/upload/arquivos/emagis_prog_cursos/ccp5-lenio. pdf. Acesso em: 22 ago. 2010. 